\title{
USKYLDIGE GLEDER, FARLIGE SLUTNINGER. SELVHAT OG FUNDAMENTALISME I KNUT HAMSUNS ROMAN DEN SISTE GLAEDE (1912)
}

\author{
ANDREAS G. LOMBN/ES
}

\begin{abstract}
Knut Hamsun's prose fiction around 1890 fulfills his programmatic intention to represent modern complex individuals. Two decades later the author steps forth to chastise the nation with simplistic reactionary truths. The hero of Hamsun's "wanderer" novels 1906 to 1912 may be taken to parody the protagonists of Hunger, Mysteries, and Pan 1888-1894. The hysteric tone in the narrator's criticism of modern society in Hamsun's 1912 novel, The Last Joy, points to a personal motivation. The ultimate pleasure in this book seems to be indulging in his own self, an experience of nothingness associated with literature. Interpreting the author's U-turn from modernist to reactionary as fueled by fear of his own findings, the lack of foundation in a world where subjectivity reigns uninhibited, this paper will focus on the implications of the narrator's professed but unclear conclusions, the reasons for and the nature of the author's political involvement.
\end{abstract}

Keywords: Hamsun, populisme, nazisme, modernitet, Den siste glæde

Ingen har større tro på diktere enn nordmenn og få har mindre tiltro til diktning. Æren for det norske "dikterveldet" har én mann, Bjørnstjerne Bjørnson, den liberale lederskikkelse som mer enn noen la grunnen for det moderne Norge. Med "Et Ord til os"1 i Bjørnsons dødsår 1910 fremmet Knut Hamsun sitt kandidatur til den ledige stillingen som dikterhøvding. Hans nederlag ble like totalt som forbildets seier. Ikke bare var personligheten forskjellig, og tiden, men også litteratursynet. Ibsen med sine grublende karakterer og gåter uten svar kunne aldri blitt en folkefører. Gjennom markedsføring verdig det moderne Amerikas åndsliv overtrumfet Hamsun mesteren med utfall mot litteraturens endimensjonale karaktertegning og gjorde det moderne sammensatte mennesket til sin spesialitet. To desennier etter gjennombruddet med den modernistiske skildringen Sult står Hamsun fram, entydig og myndig, med en flammende appell til nasjonen.

Gang på gang blusser debatten om Hamsuns svik opp: Var Hamsun nazist? Hvordan kan en god dikter være en dårlig politiker? Om vi ser bort fra dem som med Thorkild

1 Verdens Gang, 3/7 1910. 
Hansen (1978) hever kunstneriske genier over enhver kritikk, har vi dem - deriblant kommunisten Nordahl Grieg (1936) - som prøver å skille mellom dikteren Hamsun og politikeren, og holder på at vi fortsatt kan glede oss over det verdifulle i bøkene. Men politikk er ideologi, og ideologi er ikke fakta, men fiksjon. Moderne litteraturforskere som Atle Kittang (1984) og Øystein Rottem $(1978,1998,2002)$ har vist spenningene og selvmotsigelsene i Hamsuns forfatterskap. Enda er det typisk for de mange som tar opp nazi-problematikken, at de fokuserer på forfatterens holdninger som de kommer til uttrykk i polemikk og offentlig fremtreden. I liten grad tas hensyn til romanenes vitnemål, enda det er som forfatter Hamsun interesserer i første omgang. Medieuttalelser og biografiske brokker, om enn fra naziarkiver, gjelder for fakta unndratt språklig spill, og derfor bedre kilder til forståelsen av forfatterskapet enn dette selv. Har man grepet forfatteren, har man grepet intensjonen. Biografi og fiksjon er ett og har én og bare én mening. Dette førmoderne menneske- og litteratursynet råder langt inn i de profesjonelle lesernes rekker. ${ }^{2}$

Litteraturvitenskapen har som andre fag sine periodiske svingninger. Når jeg bringer inn den aktuelle dragningen mot det entydige og virkelige (ufrivillig parodiert i reality-sjangeren), er det fordi Hamsuns sene forfatterskap innebærer nettopp en reaksjon på det komplekse menneskebilde han selv tidligere hadde introdusert. Forferdet ser den middelaldrende kulturkoryféen ned i avgrunnen han hadde åpnet. Desperat griper han etter feste. Denne vendingen i forfatterskapet (liksom tilsvarende svingninger i resepsjonen) taler for at vi bør fokusere på spenninger snarere enn på fikserte posisjoner som "modernist" eller "reaksjonær".

Hamsuns politiske skyld betrakter jeg som avgjort av norsk rett. Utfordringen er sammenhengen mellom dikteren og Hitler-beundreren slik den ytrer seg $i$ forfatterskapet. Nedenfor vil jeg se nærmere på en av Hamsuns mest hatefulle romaner, ${ }^{3}$ Den siste Glode. Det er også en av hans minst kommenterte, ${ }^{4}$ trolig fordi den virker så entydig i sin hyllest av tradisjonelle norske verdier og sine utfall mot nymotens fjas. Dette er gjort rede for av Lisbeth Pettersen Wærp i hennes artikkel "Kulturkritikk og romandiktning i Knut Hamsuns Den siste gloede” (2002), som foruten å gi en forbilledlig presentasjon av teksten dokumenterer kompleksiteten så vel formmessig som i persontegning. ${ }^{5}$ I det følgende fokuseres det ideologiske aspektet av kulturkritikken.

Det er klart at bokens forteller er i krise og søker en fast grunn, noe han tror seg finne i nøysomt landsens liv og arbeid i pakt med naturen. Den påfallende aggressiviteten virker umotivert om ikke av en fornemmelse av egen tilkortkommenhet, noe som kan forklare de illevarslende om enn uklare "slutninger" fortelleren trekker med sine etter

2 “Det finnes noen litteraturprofessorlesninger," sier litteraturprofessor Tore Rem i et intervju i danske Weekendavisen, "som viser at romaner som Markens grøde ikke nødvendigvis er så entydige". Hentydningen gjelder nok Walter Baumgartner (1998) og Atle Kittang (1984) - deres nyanserte lesninger har ikke biografen mye sans for.

3 "Skildringer" med Hamsuns sjangerangivelse i førsteutgaven.

4 Like fullt vil det sprenge rammen for denne fremstillingen å forholde seg til all relevant sekundærlitteratur, så som Heitmann 2012, Iden 1995, Krouk 2011 og 2017, Legault 2018, Lyngstad 2005, Sjølyst-Jackson 2010, Henning H. Wærp 2018, Lisbeth P. Wærp 2012, Ylir 1974 og Žagar 2009.

5 "Tidsbildet og kulturanalysen er videre forbundet med en bestemt romanestetisk strategi, nemlig en kompositorisk og normmessig demontering av helheten og enheten i ulike steder og stemninger, i forskjellige masker og meninger og motstridende stemmer, posisjoner og perspektiver” (Wærp 2002: 43). 
alt å dømme uskyldige gleder som premisser. Er så disse uttrykk for en politisk ideologi som vi helst skal la ligge i skyggen, eller kan tenkemåten lære oss noe med relevans for dagens situasjon? En oppmerksom lesning av teksten i en videre sammenheng gir følgende: Med sin komplekse menneskeskildring står Hamsun fram som modernistisk forfatter av internasjonalt format, men skremmes av selvets og alle tings mangel på fundament og stabilitet. Mer og mer desperat søker han og hans litterære dobbeltgjengere trygghet - i et (allerede passé) patriarkalske samfunn og i troen på naturen. Det er en utvikling som viderefører Nagels dyrkelsen av den store ødelegger i Mysterier, og som peker ut over litteraturen, ytterst mot Hitler. Men innenfor fiksjonen skildres dette forløpet med blikk for kompleksitet og selvmotsigelser. Styrt av skrekken for menneskers (og teksters) manglende enhet, fortsetter debatten like fullt å konstruere helter (oss) på bekostning av Hamsun som skurk. Så lenge dette pågår er vi avskåret fra innsikt som til syvende og sist er innsikt i oss selv. ${ }^{6}$ Det er like skremmende som at jakten på entydige og absolutte sannheter (utenfor litteraturvitenskapen) fortsetter med samme potensielt voldelige konsekvenser som i Hamsuns tid.

Et par tiår etter suksessen med de rotløse eventyrerne i Sult (1888-90), Mysterier (1892) og Pan (1894) sender Hamsun ut en ny vandrer i romanene Under Høststjornen (1906), En Vandrer spiller med Sordin (1909) og Den siste Glode (1906-12). ${ }^{7}$ Den geniale outsideren har lykkes, han er anerkjent og økonomisk uavhengig, han er blitt eldre og ettertenksom, men definitivt ikke lykkeligere. Når han som en Dumas' musketér drar ut på nye eventyr 20 år etter, er han blitt en parodi på seg selv - i egne øyne vil si, og som alltid hos Hamsun gjelder bare den subjektive sannhet.

Den siste av disse bøkene skiller seg ut ikke bare med uvanlig grove utfall mot engelskmenn og alt som smaker av modernitet, men med regelrette maskefall der forfatteren og samfunnsdebattanten Hamsun i egen person tar ordet og skjeller ut sin leser:

Til dig, den nye ånd i Norge! Jeg har skrevet dette under en pest for en pests skyld. [-] Du vil jo ikke bli overbevist om den redelige sandhet i mine slutninger; men jeg skal tvinge endog dig til å forstå at jeg er sandheten nær. Da fraregner jeg idioten i dig. $(38)^{8}$

Nå hører provokasjoner til denne forfatterens repertoar, og skillet mellom liv og diktning er knapt relevant for en som vil skildre individuelle tilfoelder. ${ }^{9}$ Men inntrykket av krise er insisterende og fremstillingen ulikevektig på grensen til desperasjon og hysteri. Om krisen er personlig, så er det uansett en forfatters krise, én hvis identitet helt og fullt er basert på litterær virksomhet. Hva for pest kan det være som har rammet den norske ånd? Hva for glede er det som gjenstår? Og hvilke slutninger er det tale om?

6 Om jeg får dømme av personlig erfaring, er et tredje standpunkt ikke velkomment. Da jeg ved én anledning (avskåret fra den opprinnelige debatten) fikk trykt en artikkel om vanskene med å plassere Hamsuns romaner politisk, ble tittelen av redaksjonen endret til "Nazist? Ja eller nei!".

De tre første kapitlene er trykt i Samtiden, 1906, under tittelen "Vinterskoge".

8 Da kapitlene er korte, har jeg valgt å henvise til kapittel, ikke sidetall, som vil variere i forskjellige utgaver (og oversettelser).

9 "Fra det ubevidste Sjæleliv". Samtiden, september 1890. 
Den navnløse jeg-fortelleren, la oss kalle ham KP, ${ }^{10}$ sier seg å flykte fra leden og sin egen vellykkethet. Han som var "træl og vagabond" agerer landstryker, han som har vunnet bifall for sine ord, er blitt skeptisk til dem eller han får det ikke lenger til - å gjøre sine "store jærn røde". Hans stadige snakk om alder sladrer om midtlivskrise, grandiost forstørret: "Nietzsche vilde nok ha talt sålunde [-]. Jeg uttalte meg ikke i den retning, men gik bare ind i skogene." (1) Nei, KP (som Hamsun) både uttaler seg og uttaler seg ikke. Vi har å gjøre med den upålitelige forteller vi kjenner fra Pan, han som demonstrerer sin besettelse av Edvarda ved å snakke om hvor lite han bryr seg.

Den siste gloede gir til beste den livstrette forfatter og noen mennesker han møter i utmarka eller på en turistgård som utgir seg for sanatorium, mennesker han gir seg til å utspionere. En avskjediget lærerinne, "typen Torsen”, lar seg i sin lediggang kurtisere av diverse menn, foruten KP selv den virile løsarbeider Solem og en feminin "komediant". Da Torsen forlater pensjonatet med komedianten følger KP etter, men tar først kontakt følgende vinter. I mellomtiden har hun truffet den trauste snekker Nikolai, som hun senere gifter seg med tilskyndet av KP. To år etter dette da paret har fått sitt første barn, bor KP en vinter på deres avsides småbruk mens han igjen diskret lodder fruens følelser. Det synes å være hans beste tid, men noe driver ham videre: “Å disse evige reiser! Ikke før i orden på ett sted før man er i uorden igjen på et andet, ikke hjem, ikke rotfæste." (37)

Liksom hovedpersonene i de tidlige verkene har KP av uklare grunner vendt ryggen til sitt borgerlige liv, som vi ikke får vite annet om enn at han er berømt og velstående. Den eneste han synes å bry seg om, er en liten pike som vi kan tenke er hans datter. Mer enn noen barnerim blir det uansett ikke. For øvrig er han som jeg-fortelleren i Sult opptatt av sine stemninger og innfall, og som Glahn av naturen og av eros. Diktning og kjærlighetsliv sammenfattes i bildet av de røde jern, og han legger ikke skjul på at de ikke gløder som før. Ikke desto mindre er dét hva han sysler med. Skrivingen nevnes boken igjennom, men alltid bare i forbifarten, samtidig som han altså i store deler av fortellingen følger etter Torsen, selv om også dette er halvt tildekket. Naturen er viktig for KP som for Nagel og Glahn, men med en dreining. Mens den før hovedsakelig var stemningsleverandør, fungerer naturen for KP som den moderne sivilisasjonens motpol, naturen er naturlig i betydningen sedvanlig, tilvant og tradisjonell.

\section{Villmarksliv og erotikk 20 år etter}

Løytnant Glahn jaktet til husbehov, selv om veien til kramboden ikke var lang i noe henseende. KP klager på byliv og kjøpemat, men gjør ingen forsøk på å leve på naturens premisser. I sin ensomhet iscenesetter han små opptrinn med de rekvisitter som er for hånden:

Hvis jeg en dag møter en renokse så vil jeg kanskje si: Gud i himlen, der er en renokse, den er olm! Men hvis dette gjør for stærkt indtryk på mig så sier jeg det er en kalv eller et fjærkræk og lyver mig godt fuld. (1)

10 I den første av de tre vandrerbøkene, Under Høststjernen, bærer jeg-personen forfatterens opprinnelige navn, Knut Pedersen. 
Scenen i sin helhet er hypotetisk ("Hvis ... vil jeg kanskje") med artistens sideblikk til publikum ("Gud i himlen”) og språk ikke som virkelighetsgjengivelse, men som produsent av alternativ virkelighet - "sandhet" kanskje, men subjektiv. Dette er den hamsunske vandrer vi møter ennå Paa gjengrodde stier i 1949, han som suverent oppløser reelle saksforhold i verbal konfetti.

"I vinter var det i grunden så at jeg gik her og slet ondt og lærte for å tukte mig selv. [-] nu skal du ingenlunde se brød i tolv timer, så vil det gjøre indtryk på dig, sa jeg og gjemte brødet." (4) Ingen med nødvendig ærend i marka finner på slikt. Det er Sult-heltens inspirasjonsteknikk, en anorektisk øvelse ytterst beregnet på å styrke en vaklende selvfølelse og dikterevne. Slik 'helten' i gjennombruddsboken er i større behov av en krone å gi bort enn av en krone til mat, er KP avhengig av småfolk for å hevde seg. Floesketyven Eilert morer ham, gjør ham nedlatende, smått generøs og overbærende: "Eilert var ikke værst, og han var ialfald en pragtfuld hardhaus," skrønemaker med ny kone og fillete gjilde børn. (26) Eilert har vagabondens evne til å overleve og han er viril, slik er han en representant for fortellerens ungdom. På samme måte som omstreiferen og kvinnebedåreren Solem.

I utmarka som blant folk har KP ingen agenda ut over å samle stoff, han eksperimenterer med seg selv og andre. Han ymter for Solem at han vet om dennes mord på en (felles) rival, og Solem går bokstavelig overende.

Da det var gjort var alt kjedelig og tomt igjen, og for å hærme efter mig selv går jeg avsides og skriker: Mursten til slottet! Kalven er meget friskere i dag! Da det var gjort gjorde jeg andre ingenting, og da mine penger begyndte å slippe op skrev jeg et brev til min forlægger og forespeilet ham at nu snart vilde jeg sende ham et utrolig og mærkelig manuskript. (22)

Den skingrende tonen (og sviktende begrunnelse) i utfallene mot angelsaksere, eldre og alt som har med bøker og kunst å gjøre, tyster om underlegenhetsfølelse og selvforakt. Som andre turister og sportsmenn leker KP landstryker, parodierer fattigbønder og fiskere med sine turer og overnattinger i friluft, i tillegg prøver han dem ut, snylter på andres erotikk som kikker, uten større investeringer være seg av penger eller følelser.

Ikke bare viltet, også gjeterpikene får gå i fred for denne parodi på Pans løytnant. Torsen er skrekkeksemplet på den moderne kvinne: "[H]verken glæde eller sundhet eller uskyld, men studentereksamen." (9) KPs uttrykte mål er å få henne fra sine tilgjorte fakter og tillærte skolekunnskaper og realisere sin natur som mor og hederlig arbeidende småbrukerkone. Spesielt irriterende er det tydeligvis at hun gjør skuespill av sin erotikk. Etter et plumpt første forsøk lykkes Solem å sette henne på plass, for anledningen ikledt komediantens kappe og ikke mer. Virilitet og underfundighet er hva som skal til! Solem og komedianten gjenkjennes som sider ved fortelleren som ung. KP lar skinne gjennom at han selv verken er sluppet opp for kraft eller kunster, men trer tilbake for en ny figur i Hamsuns persongalleri. Det praktiske livs mann Nikolai lanseres som ideal.

Bildet av Torsen stemmer ikke helt. Muligens har hun "underernæret sin natur", men hun har et prosjekt, nemlig ham, KP. Han anklager henne for å spille ut sin erotikk for en tilskuer. Når han ser det så godt, er det fordi dét nettopp er hans egen taktikk for å 
vekke interesse og sjalusi: "1 "Hun kom og fortalte mig at hun var forlovet og så syntes hun meget ulykkelig, var det en måte!" (35) Det er utenkelig at han ikke forstår. Om han ikke gjør, må det være fordi han ikke vil bli minnet på sin egen opptatthet av tredjemand, av potensielle rivaler. Hvorfor ellers pleie omgang med råskinnet Solem eller den foraktelige komedianten eller følge etter snekker Nikolai som i langt høyere grad enn Torsen er en type? I likhet med Sult-helten ${ }^{12}$ er KP overalt og alltid opptatt av publikum. Vel fordi veien til å tro på seg selv går gjennom å overbevise andre. Han er det som bruker den unge kvinnen til å stimulere sin fantasi, puste til sine røde jorn. Han sier så meget selv, hun er bare æmne, - men da er det han selv som er gold og forkvaklet. (22)

Hva gjelder naturlig livsførsel, erotikk og arbeid har KP langt mer til felles med de utskjelte turister og byfolk enn med markas folk, som når sant skal sies heller ikke står fram som gode forbilder. Her kunne vi skrevet selvbedrager og nøyd oss med det. Men enda er vi ikke på trygg grunn. Vi kan godt tenke oss at Glahn innbilte seg at han ikke lenger brydde seg om Edvarda da han etter to år skrev sine erindringer. Men bak jeg-fortelleren finnes, her som der, en annen forteller, og denne vét. ${ }^{13}$ Den ikke-personifiserte fortelleren kunne vi kalt Hamsun, om det ikke var for at Hamsun i sin avispolemikk står last og brast med den figuren jeg har kalt KP. Mer enn en russisk dukke er den typiske Hamsun-forteller en løk: "Till det inderste indre/ er altsammen Lag, - bare mindre og mindre" (Peer Gynt, V).

\section{Jeget som alt - og intet}

KP er lydhør for erotisk stemning, men blir aldri ferdig med “å trække [s]ig tilbake og sitte i ensomheten i skogen og ha det godt og mørkt omkring mig. Det er den siste glæde" (22). Ytterst lever han som Sult-helten for inngivelser som kan fremkalle de språklige lykketreff som er forfatterskapets varemerke, og disse kommer i ensomheten. Romanhandlingen kan forstås som en vandring på ungdommens stier, den siste forelskelse eller den siste dikterraptus - dempet, nostalgisk, sett som gjennom en omvendt kikkert. Fortelleren benekter det ikke:

Bare sentimentalitet og stemning og vers og ingenting? Ja.

Det er den siste glæde. (22)

Så er det ikke kvinnen eller livet i naturen han søker, men tomhet så fantasien kan utfolde seg: "Jeg længes ingen steder hen, jeg bare længes." (21) Allerede debutboken pekte ut sult og generelt mangel som forfatterskapets drivkraft. Den sultende dikterspiren der grep de anledninger som bød seg til å utsette tilfredsstillelsen i det lengste. I de periodene han hadde mat, skrev han ikke noe som var verd å referere. Hos den mette og vellykkede

Noe han refleksmessig griper til da Torsen besøker ham på hans værelse. (35)

"Jeg er fortapt! hvisker jeg for mig selv: mine damer og herrer, jeg er fortapt!" (Sult, IV)

"Han er en detektiv som spionerer på seg selv," skriver Rottem (2002: 60) om Sult-helten: "på samme tid ukontrollert nervebunt og cool observatør". 
KP er dikterglød og eros kjølnet. Den som har nådd sitt mål, mister motivasjonen. ${ }^{14}$ I sin desperasjon iscenesetter han seg selv som vagabond og opprører. Han skylder ikke sin selvvalgte isolasjon på menneskenes ondskap, heller ikke på "at det bare er sig selv man holder ut, nei, nei”.

Men det er det mystiske at alt bruser fjærnt mot en, men alt er nær, man sitter i midten av en allestedsnærværelse. Det er vel Gud. Det er vel en selv som ledd i alt. (22)

Gud er opplevelsen av "en selv som ledd i alt;" det siste ordet i oppregningen i foregående sitat er "ingenting". Alt og ingenting. Innimellom disse passasjene i boken står et dikt, "Hvad vil mit hjærte?", der jeget er på vei mot menneskene, men vender om til skogens fred og sovner til lyden av drømte klokker i haugen. Tanken på den siste glede dukker opp igjen senere da han "tom og forlatt" har ekspedert Torsens sekk: "Det siste land, den siste $\varnothing$, den siste glæde ...” (30) Den ultimate glede er verken forelskelse eller diktning, for ikke å si familieliv eller jordbruk, men avskjeden med all higen, endeliktet under torven: å vende tilbake til alt som ingen.

"[D]ette stedet jeg nu er på det er jo egentlig ikke nogen li, men en barm, et fang," heter det eksempelvis. (12) Fortelleren sparer oss bryet med å fortolke: "Gjør jeg en gud av naturen? [...] Ingen kjender Gud, lille ven, mennesket kjender bare guder. $\mathrm{Nu}$ og da er det som jeg træffer min.” Både naturen og gud er projeksjoner, eller snarere stoff og forbilder i fortellerens vaklende selv-hevdelse. En korp har pratet til ham:

Det bølger sakte i mig og det kjendes for mig nu, som så mangen gang før i marken, at stedet nettop er forlatt, at nogen nys har været her og bare er trådd tilside. I denne stund står jeg på tomandshånd med nogen her, og litt efter ser jeg en ryg som forsvinder i skogen. Det er Gud, tænker jeg. (12)

Ja - Naturen som mor, Gud som etterbildet av dette nærvær!

Et tordenvær viser "hele naturen i oprør, et tahu vabohu": skapelsesberetningens øde og tom. Det vekker de forskjelligste følelser og innfall, gjør ham overstadig lystig og inngir stor sorg. Fjellene er i tur og orden "besværgelser mot min vandring," kolossale eder, fagforening med mere:

Jeg vil svække natten ved å rope imot den, ellers tar den mystisk alle mine kræfter og gjør mig viljeløs. [-] Men jeg nikker nogen ganger, og det skal bety at jeg er dristig og glad. Kanske er fjældene bare utstoppet også. [-] Og jeg prater og roper mit navn for å høre om det er til. (6)

Naturen er "unaturlig deilig," den er alt, men samtidig intet ettersom den ikke har annen mening enn den han vilkårlig tillegger den (“det skal bety at”); slik er den kilde til allmaktfølelse, men også til avmakt. Fortelleren agerer gud, tar kontroll over naturen,

14 Den tristaniske kjærlighetsmyte og den orfeiske kunstnermyte som Rottem (2002: 109) finner i Pan, lar begge "avstand, tap og fravær framstå som forutsetninger for en potensering av et imaginært fantasibilde - som kunstverk eller kjærlighetsdrøm". 
men det er kun i språket; det eneste han skaper er et selv som vakler fra punktum til punktum i takt med stemningsskiftene. I virkelig uvær er dette selv et fnugg og ingenting. I arresten i Sult var det språklige påhitt, i første rekke det selvskapte ordet "Kuboaa", som ga vern mot mørke og oppløsning, ${ }^{15}$ i sitatet over har navnet (som ikke nevnes) denne funksjonen, og pratet, det vil kanskje si hans fortelling i helhet.

\section{Frihet, angst og underkastelse}

Tilværelsens mangel på iboende, gitt mening er forutsetningen for de virtuose illusjonsnumre som åpnet for Hamsuns berømmelse. Men om jeget kan skapes og skapes om etter forgodtbefinnende, så er det like tomt som universet i øvrig. Etter den første skaperrus gripes forfatteren av angst. Tilværelsen blir lett, altfor lett og til sist uutholdelig. ${ }^{16}$ Desperat av mangel på faste verdier og rammer, lei av sine egne illusjonskunster, "døsig av medgang," fortvilet av mangel på virkelighet ifører KP seg hårskjorten. Forfatteren pålegger seg selv en hestekur og foreskriver nasjonen noe tilsvarende: Tilbake til jorden! Kjør ut møkk, dra sleden selv! Store barnekull! Fremfor alt ingen bøker og funderinger! Naturens orden er den eneste sikre grunn - funderer han seg fram til, i en roman.

KP er ikke asosial så mye fordi han tilbringer to-tre år utenfor tettbygde strøk og vanskjøtter sin korrespondanse (bortsett altså fra når han ber forleggeren sende penger), den ytterliggående individualisme viser seg i hans innstilling til samfunnets institusjoner. Teater, litteratur, kunst, avisdebatt, teoretisk kunnskap og undervisning har han bare forakt til overs for, mens han direkte saboterer håndhevelsen av lov og orden. Da lensmannen kommer etter Eilert, uttrykker han forakt for kjøpmannen som anmeldte ham, og for lensmannen som gjør forretning av pågripelser. Det er ikke fordi loven er for streng, men fordi den mangler autoritet:

Ak hvor et tyveri er ophørt å være noget videre! Det kommer også av at lovens straf for forseelser av alle slag er ophørt å være noget videre. Det er bare en kjedelig og human straf, man har tat det religiøse element ut av lovene, en sorenskriver er uten nogen mystik mer. (2)

Avskaffelsen av absolutte verdier i det moderne er det største onde. Er det slik at KP vil tilbake til religionens fundament?

Jeg husker den siste dommer som la ut edens betydning slik som den skulde utlægges og være av virkning. Og da isnet vi i hårroten alle i hop. Kom med litt trolddom igjen og med litt sjette [sic] Mosebok og synd mot den Helligånd og forskrivninger med nydøpt barns blod. (2)

15 Sult: Et fragment. Ny Jord, Kjøbenhavn 1888.

16 "Hamsun har ingen etiske verdier å falle tilbake på; når det er slutt med bruset, går det nedover bakke. [-] Som politiker prøver han å døyve meningsløsheten med disiplin," skriver Nordahl Grieg (sitert etter Nilsen 1960: 221). 
Nærmere sett beror ikke virkningen på den strenge Jahve, men på utlegningen, den verbale trolldom som får tilhørerne til å isne i hårroten (ikke omvendes i hodet). ${ }^{17}$ Fortelleren befinner seg stadig, så mye han raser mot den, i modernitetens tomme rom der alt er mulig - forutsatt at man kan forføre og skremme. Siden det ikke finnes noen fast grunn, kan man tillate seg alt, overse loven eller innføre én som er så fryktelig at den illuderer fast grunn. Fortelleren er reaksjonær fordi han savner sin uansvarlige ungdom, men enda mer fordi han har lykkes å gjøre uansvarlighet til norm, og fortviler over å være kastet tilbake på seg selv og dermed like fullt ansvarlig. Han skylder fra seg på alderen og på nevrasteni, "alle sykdommers apekat," i dag ville diagnosen vært depresjon, utbrenthet, angst. Da som nå gjelder angst friheten, den som fortelleren parodierer i typen Torsen, og setter seg fore å helbrede. Han har mistet troen på litteraturen og på sine røde jorn, han forkaster kunst og kunstighet og komediespill til fordel for det håndgripelige og naturlige, basale. ${ }^{18}$ Det tilvante er det virkelige.

Tomhet, besserwissenhet, sensasjonsmakeri, pengeinteresse og humbug - KP står selv ikke tilbake for de elever, turister, journalister, det pensjonatfolk og den tid han besværer seg over. Han anklager skolen for å glemme innhold for grammatikk, men de slutninger han innledningsvis sier seg å ville påtvinge leseren, bygger nettopp på konstruksjoner uten referanse, som disse murstein til (romanens) fiktive slott i sitatet fra kapittel 22 over. Og slike "ingenting" unnslår han seg ikke å kreve penger for.

I det livsoppgjør som romanen er, har KP veid seg og funnet seg for lett. Nagel holdt på at "Den store terrorist er størst, dimensionen, den uhørte donkraft som veier kloder op" (Hamsun 1992, 1: 174). Motvekten til kloden med dens liv kan neppe være annet enn den ultimate vold: døden. Men liksom barokkens dyrkelse av knokler og timeglass ikke gjaldt Døden som sådan, men det bedre liv hinsides døden, vil KP rydde plass for den virkelige storhet: Det nye liv! Nagel og Glahn endte med å ta livet av seg selv, KP fortsetter som Sult-personen på det uvisse, men med et uttalt ønske om å avskaffe både seg selv og de som ligner ham. Fordi de ligner på ham! Forresten, bort med all modernitet og den "last som den sunde skjæbne fra Tyskland en dag vil tukte til døden....” (11). Slik må vel være de slutninger som KP og hans dikter i bokens siste avsnitt vil påtvinge leseren.

Følgeriktig trer forfatteren KP tilbake for snekkeren og småbrukeren Nikolai, som ikke forliter seg på ord, men uttrykker seg fysisk: Solemens "kjønskollega, en hest av kræfter og balstyrighet”. (37) Da passer det at Torsen har gitt skolekunnskapen på båten og sluttet å gjøre "kunster med [s] ig selv"; hun vil ha barn "som orgelpiper, den ene høiere end den andre" - og sier dette mens hennes nesebor gikk ut og inn, "hun var som en hoppe". (36) Livskraft er det ultimate gode. Da Solem tar livet av rivalen, faller det ikke fortelleren inn å melde ham. Solem får (til sist) sin straff av Nikolai, det er naturens egen justis. Å bringe ham for sorenskriveren ville vært å forråde naturen selv.

Ideologens triumf er erotikerens nederlag. Bitterheten i det siste kapitlet er slående. Men merker vi ikke også den skapende kunstners misnøye med det ferdige og formulerte,

17 Den ideale familie KP har bidratt til å forme, er da heller ikke troende, men leser andakten av konvensjon. (36) Her kan man tenke på sosiologen Max Webers tanke om "avfortryllelse", die Entzauberung der Welt, og den konservative utnyttelsen av fenomenet.

18 Det er et prosjekt i forlengelsen av Sult. Rottem (2002: 58-59) oppfatter "Sult-heltens ekstreme opptatthet av tingene $[\ldots]$ som et uttrykk for en desperat selvbergingsaksjon": "Han besverger så å si virkeligheten, maner den fram, overtaler seg selv om at det faktisk fins en sansbar realitet utenfor hans egen tankeverden." 
behovet for å gjøre rent bord og begynne på nytt? "Hvorfor jeg har skrevet slik? Fordi min sjæl skriker av kjedsomhet foran hver jul, over de samme bøker skrevet på den samme måten."

Jeg har skrevet om mennesker. Men inde i den tale som sies føres en anden, den går som åren under huden, en roman i romanen. Jeg fulgte litteraturens begyndende syttiåring skridt for skridt og rapporterte fra hans opløsningsproces. (38)

Dette må nok klassifiseres som et maskefall. Hamsun rapporterer fra sin egen oppløsningsprosess og "bekjender" sin svekkede dikterevne ("De er tænkt så store og så røde; men de er små jærn og de gløder lite”), enda hans bok "trods alt skiller sig ut fra de andres ingenting”. Ytterst er det troen på litteraturen, hans egen geskjeft, som er anfektet. Han skylder på middelmådighetene, han skylder på sine unge år da, og på sine mange år nå, selv kunne han ikke bringe en renossance:

Men nu skulde du, min bittelille ven, se dig om: det er dukket op [...] en skinnende fjærbusk, rike sløsere, talenter under åpen himmel, [-] ungdom med ædelstenen i øiet. (38)

Det er langt fra klart hva dette referer til, billedspråket peker i et hvert tilfelle ut over språket mot krigersk dåd under åpen himmel, mens han forkaster seg selv i egenskap av 50-årig "begyndende syttiåring" og (rim)smed med lunkne jern. ${ }^{19}$ (36)

Den siste glede er i tur og orden å trekke seg tilbake, sitte ensom i skogen og ha det godt og mørkt omkring seg (22), konkretisert i tomheten etter at KP har ekspedert Torsens sekk uten avsenderadresse (30), kort sagt "sentimentalitet og stemning og vers og ingenting" (22). Er det snakk om én glede? I så fall er det tilbaketrekningen til det "ingenting" som er jeg-følelse - og litteratur. Når alderen kommer, er det barn som er "den siste glæde," heter det siste gang uttrykket brukes. (36) Romanens sikte er til syvende og sist ikke mer ungdommens kreative kraft enn alderens forfall, men livet som u-stanselig fornyer seg selv i den naturlige syklus: "renæssance", gjen-fødelse! KP hjelper i all uskyld det friske mot det avfeldige:

en liten bælgvækst, den er så underlig sagte av sig, litt frø tyter ut av den, - å Herregud, den står og skal være mor. Den er kommet i vase med en tørkvist og jeg befrier den. Livet går gjennem den, solen har endelig varmet den idag og kaldt den til sin bestemmelse. (23)

Livet har sin bestemmelse, men den sentimentale vitalist har ikke helt troen, naturen trenger en hjelper og refser for riktig å bli naturlig sunn.

Her hvor dyrkelsen av det naturlige og håndgripelige slår over i sentimentalitet, kommer KP interessant nok inn på noe som skal bli det ideologiske fundament for tyske SS. Både Rosenberg, Goebbels og Himmler kom til å koble forestillingen om en kvasi guddommelig kraft som omfatter liv og død, med kallet til å utrydde det livsudugelige og

19 Britt Andersen (2011: 84) oppfatter “åren under huden" som et vink om "at teksten rommer 'levd liv' og at vi derfor har å gjøre med selvfiksjonalisering”. I tråd med sitt kjønnspolitiske perspektiv vektlegger Andersen det person-historiske, mens jeg fokuserer på det litteratur-historiske ("litteraturens begyndende syttiåring $[s-]$ opløsningsproces"). Det er ikke snakk om et enten-eller. 
unaturlige. Det betyr ikke at KP er nazist før tiden. Med mennesker har det hos Hamsun ingen nød, "det menneske som duger går [...] sin egen vei”. (32) Det man behøver, lærer man best hjemme - så får man det "ind i blodet" (36), skoler "har svækket vor sunde tålsomhet til å bære”. (32) "Den mand som ikke trodser i motgang duger ikke, lat ham gå under!” (21) Dét er ikke nazisme, men liberalisme. - Forresten, skal man bore eller trodse? Er det slik at de som er født til det, skal trosse, de andre tåle? Akkurat dét er et synspunkt langt eldre enn både liberalisme og nazisme.

\section{Modernitet og reaksjon}

Stormakten England står i Den siste gloede for den moderne tid med industrialisering, arrogant pengemakt, turisme, seksuell perversjon og aldring (!); det lille turistlandet Sveits står for flid og underkastelse - jeg ser ingen andre fellestrekk enn folkestyre, parlamentarisme eller referendum. Turisme, hermetikk og alt som ikke er av nødvendighet, står mot selvforsørgende jordbruk. Romanen har klar brodd mot den modernisering av det norske samfunnet som skyter fart etter 1905, men sikter mot dens bivirkninger og overflateeffekter uten å ense de teknologiske, økonomiske og politiske årsaker. Skolegang, kvinnefrigjøring og turisme er kilde til alt ondt. I dette er Hamsun høyreekstrem og populist: Affekt for argument, fyndord for begrep, person for sak, lutter folkelige forestillinger og fordommer. En handelsmann skal være en nessekonge som ikke savner en stjålet fleskeside, loven like selvsagt drakonisk. I kraft av den får tyven skjebne og dermed sin særegne storhet, mens herremannen kjennes på sløsende overskudd og medfødte evner. Det er stilisert romantisering av Den gamle tid på ukebladnivå. I sitt maskefall krever ikke forfatteren ære for sitt egenartede skriverarbeide, det var ikke hans fortjeneste, “jeg var født med ævnerne til det”. (16) ${ }^{20}$

Hamsuns univers er et univers med naturgitte sakrale verdier, det er eventyrets verden - som på 1900-tallet blir filmens, massekulturens og propagandaens verden. Fra sin folkelige forestillingsverden henter han fantasmer og holdninger som på tysk grunn inspirerte og ga drivkraft til nasjonalsosialismen som politisk system. Fantasmer som etter hvert ble kodifisert i den nasjonalistiske völkisch-ideologien utformet av språkviteren Paul de Lagarde, i arkeologen Julius Langbehns anti-rasjonalistiske livskraft og avlsforskeren Walther Darrés Blod og jord-mystikk (Blut und Boden). ${ }^{21}$ At slike tanker (eller fantasier) utbres i Tyskland i Hamsuns ungdomsår, gjør det neppe verd å søke direkte påvirkning. Nasjonale bonde- og nyromantiske, irrasjonelle og vitalistiske forestillinger utgjør jordsmonnet også for tidens norske litteratur.

Konteksten for Lagardes og Langbehns kulturkritikk er industrialisering og urbanisering, sekularisering, pengemakt - verdikrise som følge av oppbrudd fra landsbyfelles-

20 Dette er det klareste uttrykk for nedarvet evne og dermed "rasisme" i boken. Lappegrynet Olga kalles "høne" og blanding av menneske og dværgbjørk (26), det er visst ikke (særlig) ondt ment her hvor naturen er høyeste verdi? Når Nikolai omtales som "dette stærke og sunde dyr" (36), er det en kompliment. Men muligens er natur ikke nok? Iallfall ikke for Torsen, som sier "vi vil være mennesker" (37). Når Nikolai ikke evner å følge opp i fortellerens dobbeltkommunikasjon, finner selv KP idealmannen lovlig dryg: "den mand fik da aldrig munden op heller" (37).

21 Nærmere sammenligning ville definitivt vært interessant, spesielt om man trakk inn flere skribenter enn bare Hamsun. C. M. Frølands Nazismens idéunivers, 2017, har gode sammenfatninger. 
skap, fragmentering av autoritet og familie, skjerpede sosiale og politiske motsetninger. Motgiften tilbyr seg selv. Rotfasthet, fellesskapsfølelse, organisk helhet og nasjonal enhet samt jord og "himmel", det vil si ånd/mysterium, til å balansere trivialiteten. Det er høyromantikkens veletablerte verdier, intet radikalt nytt. Likevel er motoren i det moderne: individualismen - romantikkens kjerneverdi - revurdert. Selv-hevdelse og underkastelse inngår hos nasjonalsosialistene den destruktive forbindelse vi finner hos KP.

1880-tallets positivisme og fornuftstro ledet følgeriktig oppmerksomheten mot det irrasjonelle og subjektive. Idet oppmerksomheten, som i Obstfelders berømte dikt "Jeg ser", vendes fra det sette til den som ser, fra objekt til subjekt, viser det siste seg å være uten substans. Jegets oppløsning er light-versjonen av Guds død. Umiddelbart oppleves den som en befrielse, i et hvert tilfelle åpnes for kunstnerisk nyskapelse som berettiger inntrykket av ny romantikk - med Hamsun som frontfigur. I tilbakeblikk representerer omkastningen ikke mer enn et perspektivskifte: fra substans til dynamikk og struktur/ relasjoner, fra hvem man er, til hvor man står og hva man gjør. Ikke verdens undergang, kunne man tro. Men slaget treffer en generasjon som neppe er kommet seg etter tapet av den universelle garant for sannhet og mening: den selvfølgelige gudstro. ${ }^{22}$ Påfallende raskt søker de tidlige modernister seg til frelseslærer med - hvor ulike de ellers er - absolutt fundament, fysisk eller metafysisk: katolisisme, teosofi, antroposofi, oxfordbevegelse, kommunisme, fascisme. ${ }^{23}$

Om vi leser Hamsun samlet kan vi følge historien fra 90-tallsbøkenes eksplosive kreativitet i frigjøringen fra det gamle samfunnets religiøse og kunstneriske rammer, gjennom angst og uro over manglende fast grunn i det moderne til den reaksjonære nostalgi for standssamfunnet og det hodeløse rop på sterk mann. De "slutninger" forfatteren kommer fram til i Den siste Gloede, er for all del uklare, men peker uten tvil mot aktivisme utenfor litteraturen; gleden derimot er definitivt subjektiv og litterær. Det er modernistens desperasjon over å være henvist til språket og språket alene.

\section{Antimoderne modernist}

Hamsuns fantasiverden må være førmoderne, som forfatter tilhører han en internasjonal elite av modernistiske kunstnere. Med sine små erotiske intriger og sin uttrykkelige tendens kan riktignok Den siste gloede synes gammeldags - om det ikke var for "de hemmelige Bevægelser, som bedrives upaaaktet paa de afsides Steder i Sjælen, den Fornemmelsernes uberegnelige Uorden”... ${ }^{24} \mathrm{Og}$ ironien.

22 Slik kan fortelleren i Sult ikke karakteriseres som troende, enda er han som Ragnhild Hagen Ystad (2004) viser, styrt av religiøse forestillinger. Spørsmålet om tro eller ikke-tro blir misvisende.

23 Erkemodernisten T.S. Eliot ble anglo-katolikk, imagisten etc Ezra Pound og futuristen F.T. Marinetti ble fascister, W. B. Yeats var teosof, Gottfried Benn nazist og Vladimir Majakovskij bolsjevik, franske surrealister som Paul Éluard ble kommunister. Danske Johannes Jørgensen var symbolistisk samlingsfigur før han 1896 konverterte og gikk over til å skrive helgenbiografier, her hjemme gikk Alf Larsen fra Baudelaire til Rudolf Steiner og farlig nær NS, for det norske modernisme-ikonet Rolf Jacobsen gikk veien til NS og senere katolisismen - og så videre inntil tredjefasemodernister som Dag Solstad organiserte seg for væpnet revolusjon omkring 1970.

24 "Fra det ubevidste Sjæleliv". Samtiden, september 1890. 
KP bryter ut i hat og forakt, men viser oftest ualminnelig innsikt i de forskjelligste slags mennesker; den modernistiske (innskrevne) fortellerinstansen er ironisk, og ironien rammer tendensforfatteren KP. Forenklingene yngler og blir konsekvent motsagt. Mens avisdebattanten Hamsun anvender sin ferdighet til å suggerere sammenheng, viser romanforfatteren opp bruddene i den egne argumentasjonen. ${ }^{25}$ Det ideologiske budskapet som det kommer fram i avslutningskapitlet og ellers i Den siste gloede, er overtydelig og punkt for punkt underminert. De i forbifarten påpekte selvmotsigelser og sviktende premisser er (liksom KPs ovenfor nevnte forfølgelse av Torsen) tildekket så halvveis at de nettopp springer i øynene, på samme måte med troverdigheten hos forteller og romanfigurer. I stedet for å samles til en forførende fortelling (som i Markens grøde) står i Den siste gloede hvert enkelt element fram ironisk dobbelteksponert.

KPs erfaringer er forståelige inntil det banale og hans reaksjon langt på vei rimelig. Å være mot konsumsamfunnet og tilhenger av økologisk jordbruk er det ikke noe galt i, og det må være legitimt å kritisere utdanningssystemet, til og med å gå inn for økte fødselstall (i det minste i Norge, i 1912). Det sammensatte, som er en kvalitet ved boken, ytrer seg hos hovedpersonen som en fatal splittelse. KPs idealer er knyttet til det entydige, praktiske selvet, som er det tradisjonelle subjektet, ikke det moderne som utvilsomt er hans eget. Likheten med de middelmådige andre tildekkes av hans snakk om alder, den personlige investeringen røper seg i den aggressive tonen. Selvhat rammer den som ikke lever opp til egne forventninger.

Problemet er ikke modernismen forstått som det estetisk moderne. At tapet av substansielt jeg registreres i litteraturen, betyr ikke at det er forårsaket av litteratur. Hva, om noe, er for øvrig "tapt"? Det avgjørende er reaksjonen. For dem som ikke selv har erfart noe "tap", vil ondet være den moderne gudløshet. Selv er de uanfektede i sin tro. For dem som har erfart tapet, står valget mellom fortrengning eller aksept. Å godta at mennesket er overlatt til sin frihet, innebærer at tingene, selvet og verden aldri har hatt en iboende mening. Situasjonen er krevende, men på ingen måte håpløs. Mellom disse ytterpunktene finner vi modernistene fra Baudelaire til Paal Brekke: ute av stand til å tro, ute av stand til å gi avkall på tro, desperat på leting etter et ståsted som de bare prekært og foreløpig innretter i kunsten. Fundamentalist er den som har funnet sin plattform, bokstavelig. Tvilen er plassert hos andre, selvhatet får mål og retning idet det projiseres. Om anledningen byr seg, kan den enerverende kampen med egne skygger bli en virkelig kamp med virkelige fiender og virkelig vold - etter omstendighetene kommunistisk, religiøs, nazistisk. Vi er ved det tilbakevendende spørsmålet om Hamsuns nazisme.

Å kategorisere Hamsun som nazist er betryggende for så vidt som det onde får en fysisk kropp på sikker avstand fra oss selv. Og vi slipper å lese bøkene. Om vi tar dét bryet, kan hende vi finner det ondes røtter på nærmere hold, i noe som virker fortrolig og selvsagt. Det vi kan lære av den reaksjonære modernisten er mekanismene som gjør det hjemlige (eller altfor-hjemlige) til noe unheimlich, uhyggelig og skremmende. Det onde kan da ikke lenger behandles som en smitte, men som en gift som kokes av ingredienser fra hvermanns kjøkken, på bruddstykker av slikt "alle" vet, satt sammen til onde konspirasjoner og besnærende enkle frelseslærer. Sannheten er subjektiv, "redelig” heter

25 Til og med “det ukreperte lik," 90-åringen, får et vennlig ord - av datteren. (33) Jfr Bjarne Markussen (2011) om forskjellen i omtalen av "barnemorderskene" i Markens grøde og i Hamsuns avisinnlegg. 
det i romanens aller siste avsnitt, ikke desto mindre skal leseren tvinges. Av den som behersker språket (eller i dagens situasjon media). Det er språkets makt.

Da det ble gjort politikk av Lagardes og Langbehns svermeri, var det nasjonal enhet og renhet som ble betont, antisemittisme, anti-kosmopolitisme og antiparlamentarisme kombinert med militære idealer som ære og offervilje: Ein Volk, Ein Reich, Ein Führer! som det kom til å hete. Bortsett fra antiparlamentarisme finnes lite slikt i Hamsuns romaner. I Den siste gloede er vi vitner til avmakt som slår over i voldsfantasier når selvforakten projiseres. Fundamentalisme er drøm om en absolutt og objektiv sannhet som kan legge grunnen for normer, atferd og politikk. En slik drøm er kanskje uomgjengelig, slik også dagens nypositivistiske litteraturforskning viser, men farlig om den tas for selve virkeligheten. Enda vet vi at fantasier blir reelle om anledningen byr seg. Hamsun fantaserte, støttet okkupasjonsmakten og ble dømt for det. Men hans lesere var advart. Uten å være nazistisk kan Den siste gloede lære oss noe om det stoff, de holdninger og idealer nazisme i likhet med andre ideologiske plattformer er laget av.

\section{LITTERATUR}

Andersen, Britt. "Sivilisasjonens sykdommer". Ubehaget ved det moderne. Kjønn og biopolitikk i Hamsuns kulturkritiske romaner. Tapir Akademisk Forlag: Trondheim, 2011. 51-91.

Baumgartner, Walter. Den modernistiske Hamsun. Medrivende og frastøtende. Oslo: Gyldendal, 1998.

Beyer, Edvard. "Hamsun og Hamsun-problemet" i Forskning og formidling. Oslo: Aschehoug, 1990. 133-148. Frøland, Carl Müller. Nazismens idéunivers. Oslo: Vidarforlaget, 2017.

Grieg, Nordahl. "Knut Hamsun" Veien frem. Artikler i utvalg. Oslo: Gyldendal, 1947. [Veien frem, oktober 1936]. Hamsun, Knut. Samlede verker. Oslo: Gyldendal, 1997. Bind 1 (Sult, Mysterier), bind 2 (Pan), bind 7 (Den siste gloede).

Hansen, Thorkild. Prosessen mot Hamsun. Oslo: Gyldendal, 1978.

Heitmann, Annegret. "'Herlige Ulykker. Turisme i Knut Hamsuns Den siste glede”. Hamsun i Vesterålen 2012. 12 foredrag fra Hamsun-dagene $i$ Vesterålen. Hamarøy: Hamsun-selskapet, 2012. 149-163.

Iden, Stein. Å bygge broer uten å forene motsetninger. En sammenliknende analyse av Den siste glæde og På gjengrodde stier av Knut Hamsun. Hovedoppgave i allmenn litteraturvitenskap, Bergen: Universitetet i Bergen, 1995.

Kittang, Atle. Luft, vind, ingenting. Oslo: Gyldendal, 1984.

Krouk, Dean. "Sideshadowing Hamsun’s fascism". I: Dingstad, Ståle (et al. eds.): Knut Hamsun. Transgression and worlding. Trondheim: Tapir Academic Press, 2011.

Krouk, Dean. Fascism and modernist literature in Norway. Copenhagen: Museum Tusculanum Press, 2017.

Legault, Yannick. Hamsun. Romans autobiographiques, figures d'auteur et champ littéraire. Préface de Helge Vidar Holm. Québec: Presses de l'Université du Québec, 2018.

Lombnæs, Andreas G. "Selviscenesettelse og -bedrag" i Seg selv. Subjektfrem-stillinger i norsk litteratur. Oslo: Novus, 2015. 159-188.

Lyngstad, Sverre. Knut Hamsun, Novelist. A critical assessment. New York: Peter Lang, 2005. 143-157.

Markussen, Bjarne. "Markens døde. Forbrytelse og straff i Hamsuns Markens grøde". Edda. Nordisk tidsskrift for litteraturforskning, 2, 2011. 124-141.

Nilson, Sten Sparre. En ørn i uver. Knut Hamsun og politikken. Oslo: Gyldendal, 1960.

Rem, Tore. Knut Hamsun. Reisen til Hitler. Oslo: Cappelen, 2014.

Rottem, Øystein. Knut Hamsuns Landstrykere. En ideologikritisk analyse. Oslo: Gyldendal, 1978.

Rottem, Øystein. Knut Hamsun. Guddommelig galskap. Oslo: Gyldendal, 1998.

Rottem, Øystein. Hamsun og fantasiens triumf. Oslo: Gyldendal, 2002. 
Sjølyst-Jackson, Peter. Troubling legacies. Migration, modernism and fascism in the case of Knut Hamsun. London: Continuum, 2010.

Wærp, Henning Howlid. "Hele livet en vandrer i naturen". Økokritiske lesninger i Knut Hamsuns forfatterskap. Stamsund: Orkana akademisk, 2018.

Wærp, Lisbeth Pettersen. "Kulturkritikk og romandiktning i Knut Hamsuns Den siste gloede". Norsk Litteraturvitenskapelig Tidsskrift, 1, 2002.

Wærp, Lisbeth Pettersen. "[M] it hjærte sitter med rynker". Sanatoriet som heterotopi i Den siste glæde (1912)". Hamsun $i$ Vesterålen 2012. 12 foredrag fra Hamsun-dagene i Vesterålen. Hamarøy: Hamsun-selskapet, 2012. $165-191$.

Ylir, Einar Hans. Den siste Glode. Ein analyse av den tematiske samanhengen. Hovedoppgave, Oslo: Universitetet i Oslo, 1974.

Ystad, Ragnhild Hagen. "Religiøsitet i Knut Hamsuns Sult", Edda. Nordisk tidsskrift for litteraturforskning, 3, 2004.

Žagar, Monika. Knut Hamsun. The Dark Side of Literary Brilliance. Seattle: University of Washington Press, 2009.

\section{Andreas Gisle Lombnoes \\ University of Agder \\ andreas.g.lombnas@uia.no}

